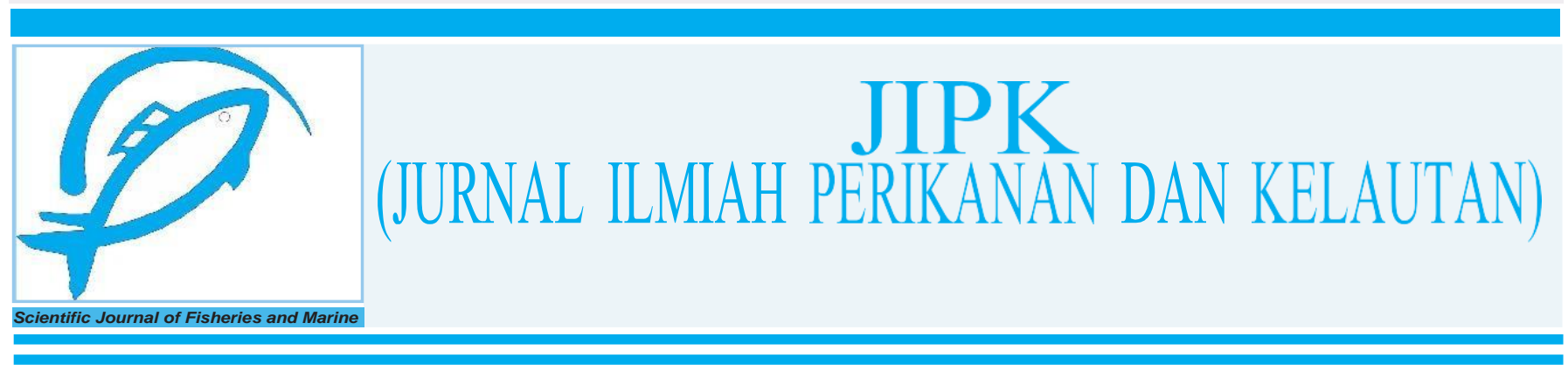

Research Article

\title{
Exploration of Antimicrobial Potency of Mangrove Symbiont against Multi-Drug Resistant Bacteria
}

\author{
Delianis Pringgenies $^{1 *}$ (D), Wilis Ari Setyati1 ${ }^{1}$ Ali Djunaedi ${ }^{1}$, Rini Pramesti ${ }^{1}$, Siti Rudiyanti² $^{2}$, and Dafit Ariyanto $^{3}$
}

${ }^{1}$ Department of Marine Science, Faculty of Fisheries and Marine Science, Universitas Diponegoro, Semarang, 50275. Indonesia

${ }^{2}$ Department of Fisheries. Faculty of Fisheries and Marine Science, Universitas Diponegoro, Semarang, 50275. Indonesia

${ }^{3}$ Department of Aquaculture, Faculty of Agriculture, Universitas Asahan, North Sumatera, Kisaran, 21224. Indonesia

\section{OPEN ACCESS}

\section{ARTICLE INFO}

Received: April 02, 2021

Accepted: June 10, 2021

Published: September 28, 2021

*) Corresponding author:

E-mail: pringgenies@yahoo.com

Keywords:

Antimicrobial potency

Anti MDR microbe

Mangrove symbiont

Rhizophoraceae

This is an open access article under the CC BY-NC-SA license (https://creativecommons. org/licenses/by-nc-sa/4.0/)

\section{Abstract}

Antimicrobial property of mangrove symbiont have the ability to fight Multi Drug Resistant bacteria which were Staphylococcus aureus, Escherichia coli, and Vibrio haryeyi. This study aimed to determine the potential of symbiont microbes from the root of Rhizopora mucronata and Acanthus iilicifolius as antimicrobial agents againstmultidrug resistant (MDR) pathogenic microbes. This research was conducted duringJuly to November 2020. The MDR bacteria were $S$. aureus, E. coli, and V. harveyi MDR test microbes. The symbiont microbes were identified through molecular analyses (PCR 16S rDNA). Isolation of symbiont microbes from $R$. mucronata resultedin 16 isolates, while isolation from A. iilicifolius resulted in 14 isolates. Based on theantimicrobial qualitative test against $S$. aureus, 8 out of 16 microbial isolates from R.mucronata were found to show antimicrobial properties. The testing of A. ilicifolius symbiont microbes against $S$. aureus showed 8 out of 14 isolates with antimicrobial properties. The test against $E$. coli resulted in 2 out of 16 microbial isolates from $R$. mucronata and 5 out of 14 isolates from $A$. ilicifolius with antimicrobial properties. The test against $V$. harveyi resulted in two out of 16 microbial isolates from R.mucronata and 4 out of 14 isolates from A. ilicifolius with antimicrobial properties. Thequantitative test found 2 isolates from $R$. mucronta, namely isolates RM10 and RM12,with antimicrobial properties against MDR strain E. coli, with the best isolate being RM10, which produced $11.22 \mathrm{~mm}$ of inhibition zone diameter. Furthermore, the selection of isolates was based on the size of the inhibition zone, the clearness of the inhibition zone and the potential for antibacterial activity. Based on their overall anti-microbial potential against the test microbes, four isolates were selected. Molecular analyses of RM12 isolate showed 95\% homology with Bacillus subtilis, of RM 10 isolateshowed $97 \%$ homologywith Bacillus oceanisediminis, of AC isolateshowed 96\% homology with Paracoccus caeni, and of AC 5 isolate showed $89 \%$ homology with Bacillus circulans. The study found four isolates with antimicrobial potency against MDR pathogenic microbes. The symbiont microbes taken from $R$. mucronata and A.ilicifolius were determined to be of the genus Bacillus and Paracoccus.

Cite this as: Pringgenies, D., Setyati, W. A., Djunaedi, A., Pramesti, R., Rudiyanti,S., \& Ariyanto, D. (2021). Exploration of Antimicrobial Potency of Mangrove Symbiont against Multi-Drug Resistant Bacteria. Jurnal Ilmiah Perikanan dan Kelautan, 13(2):222-232.

http://doi.org/10.20473/jipk.v13i2.26199 


\section{Introduction}

Mangrove is a common species spread throughout the Indo-Pacific region. In Indonesia, mangrove can be found in shallow waters along the Indonesian coastal regions (Ariyanto et al., 2018a; Ariyanto et al., 2019a; 2019b). After the 2004 Aceh tsunami which devas- tated the region and its immediate vicinity, there has been a rising awareness of the importance of mangrove ecosystems among the community in the affected areas. Mangrove green belt cannot stop an extreme tidal wave in its entirety, however, it can mitigate the destructive impact from such natural disaster (Osti et al., 2009). After this incident, Indonesian people together with theGovernment planted mangroves to improve the man- grove ecosystem on the Indonesian coast. Moreover, mangrove can be used as a source nutrition and habitat for marine organism (Ariyanto et al., 2020; Ningsih et al., 2020). The high level of nutrients in the mangrove area was caused by the mangrove waste, which turned into mangrove litter and was decomposed by bacteria, making it useful as a nutrient. Mangrove extract has proven potential as a multi-drug resistant anti-bacterial (Pringgenies et al., 2020). Mangrove symbiont bacteriawere thought to have the potential to be anti-bacterial because the active compounds in the symbiont were suspected to be similar to the host.

Various species of mangroves has been identified. Two species are particularly abundant along the coastal area of Jepara, namely $R$. mucronata and A. ilicifolius. $R$. mucronata is a true mangrove species (Quadros and Zimmer, 2017), meaning that its natural habitat are areas which are affected by oceanic tides. On the other hand, A. ilicifolius is a pseudo-mangrove species in that it is only associated to mangrove plants (Ragavan et al., 2015). True mangrove species generally have special adaptive mechanisms which help them thrive in their natural habitats. Pseudo-mangrove species do not have these special adaptive mechanisms, instead they have high environmental tolerance which allow them to live in the environment typically classified as mangrove ecosystem (Yang et al., 2015).

Dead mangrove leaves decomposes on the ground and turn into source of nutrition which contributes to their immediate vicinity (Ariyanto et al., 2018b). The decomposition process is enabled by microbes which are found in the mangrove ecosystem. Symbiont microbes of marine life can act as antimicrobial agents, even against Multi-Drug Resistant (MDR) strains. The MDR microbes are pathogenic strains that have mutated and become immune to a range of antibiotics.
Studies found that the symbiont microbe in gastropod Conus miles has the potential to be used as anti MDR microbeagents (Pringgenies et al., 2019). The symbiont microbe in gastropod Pleuroploca trapezium has potential to be used as anti MDR microbe agents, of which the microbe is identified to be closely relat- ed to Paracoccus sp. MBIC4019 with 95\% homology (Pringgenies and Renta, 2014).

There are four significant factors to make microbes resistant to antibiotics, namely permeability, inactivation process by enzymes, change of the target's receptor cells, and the increase in the synthesis of antagonistic metabolites (Ventola, 2015). Moreover, resistant microbes, which are initially sensitive to antibiotics, may happen through the mutation in their chromosomesor the exchange of genetic materials between microbes. Exchange of chromosome material is rarely found and genetic material exchange is commonly the case. Based on the findings above, this study aimed to determine the potential of symbiont microbes associated with $R$. mucronata and A. ilicifolius as the source of anti MDR microbial agent and to identify the symbiont microbes which are active against those MDR strains.

\section{Materials and Methods}

\subsection{Sampling}

This research was conducted from July to November 2020. Symbiont microbes from one root of $R$. mucronata and A. ilicifolius werecollected from Jep- ara waters and its immediate areas. The samples were then placed inside polyethylene bags (Whir-pak, Nasco, USA) and stored in a cooling container.

\subsection{Media Preparation}

Zobell agar is a non-selective agar mediummade by mixing 0.25 grams of peptone, 0.05 grams of yeast, and 1.5 grams of bactoagar with $100 \mathrm{ml}$ of dis- tilled water in an Erlenmeyer flask. The medium is homogenized on a hotplate and stirred with a stirring rod. After the medium became homogeneous, it is sterilized using an autoclave for 15 minutes at $121^{\circ} \mathrm{C}$. Liquid $\mathrm{Zo}-$ bell medium is made using the same steps, except it does not use bactoagar as a solidifier.

\subsection{Isolation of Microbes and Purification of Microbial Isolates}

A total of $10 \mathrm{~g}$ mangrove sample was immersed in $90 \mathrm{ml}$ of sterile saline water and then diluted until $10^{-}$ ${ }^{1}, 10^{-2}$, and $10^{-3}$ dilutions. Using pipettes, $100 \mu \mathrm{l}$ of 
each dilution was dripped into the prepared Zobell 2216E in Petri dishes. The preparation was then spread and incubated for $2 \times 24$ hours at room temperature. The puri- fication of microbial isolate was performed using streak method. Streak method is used in obtaining purified mi- crobial isolates. Microbial colonies are sorted out basedon their morphological characteristics and then purified using streak plates (Badieyan et al., 2018)

\subsection{Qualitative andQuantitative Test of Antimicro-bial Properties}

The test of S. aureus, E. coli, and V. harveyi wereobtained from the repository of Doctor Kariadi, General Hospital Semarang. The qualitative test was performed using overlay method according to Jiang et al. (2013). The overlay method used two agar plates which was placed on top of one another. A total of 10 microbial isolates were inoculated on petri dish and incubated for $4 \times 24$ hours. Each preparation was then added with soft agar media, inoculated with test microbe, and incubated for 24 hours. The positive control test was performed using the antibiotic Streptomycin which was tested against the test bacteria with a concentration of $80 \mathrm{~g} /$ disk. The interaction between the isolates and microbes test might form transparent zone on the periphery of the isolate. The results of this test were used to determine the potency of symbiont microbe as MDR antimicrobial agents. Agar diffusion method is used in the quantita- tive antimicrobial properties test (Balouiri et al., 2016). In this method, the zone of inhibition resulted from the interaction between the isolate and test microbes is mea-sured using calipers (Altarugio et al., 2018).

\subsection{Identification of $R$. mucronata and A. ilicifolius Symbiont Microbes}

Screened microbial isolates were identified using molecular DNA method. In order to determine the microbes, the microbial isolates were put through DNA extraction process. The resulting DNA genomes were added with $200 \mu \mathrm{l}$ of instagene matrix. The mixture was then put into a heat block at $56^{\circ} \mathrm{C}$ for 15 minutes and into centrifuge at 2,000 rpm for 3 minutes. The resulting supernatants are used in 16S rDNA PCR amplification. The PCR amplification is performed by using universal primers (Sune et al., 2020).

The amplified DNA is put through electrophoresis to determine DNA bands. The observation of the DNA band using UV. The parts of DNA band formed are thenpurified and amplified using $765 \mathrm{R}$ and $1141 \mathrm{R}$ primers in 30 cycles. Afterwards, the sequencing is performed using an automatic DNA sequencer device. The result of the PCR sequencing were then sent to PT. Genetics Science Indonesia, which is in Jakarta for the sequenc- ing of the nitrogen bases.

\subsection{Data Analysis}

The data obtained were analyzed using descriptive method. The homology of DNA sequence was determined using BLAST. The BLAST analysis results were then compiled into a phylogenetic tree using Clustal $\mathrm{X}$ Version 1.60 .

\section{Results and Discussion}

\subsection{Isolation of Mangrove Symbiont Microbe}

Isolation of symbiont microbes from $R . m u$ cronata and A. ilicifolius resulted in 16 isolates and 14 isolates respectively. The microbial isolates are categorized based on their color, shape, texture, and margin. There were seven isolates of microbes from $R$. mucro- nata which were predominantly white: isolates RM6, RM9, RM10, RM11, RM12, RM13, and RM16 as well as four isolates from A. ilicifolius, which are: isolates AC7, AC10, AC11, and AC14. Out of all isolates from $R$. mucronata were predominantly circular, with seven of them observed to be in this form, namely isolates RM3, RM4, RM5, RM9, RM10, RM13 and RM14, and 10 of them were convex in texture, namely isolates RM1, RM3, RM6, RM7, RM8, RM10, RM12, RM13, RM 14, and RM16. The most predominant shape for A. ilicifolius isolates were circular, with six isolates, name- ly AC1, AC3, AC5, AC6, AC10 and AC13 showed this shape. The most prevalent texture for A. ilicifolius iso- lates were convex, with 10 isolates showing this texture, while the other four, isolates AC5, AC6, AC9 and AC11, showed crateriform. Most isolates from both mangrove species were observed to have even margins.

\subsection{Antimicrobial Activity Screening}

The qualitative test results against MDR strain of $S$. aureus, E. coli, and V. harveyi indicated that eight isolates from each mangrove species possess antimicrobial activity against MDR strain S. aureus. Qualitative test results of Symbiont Microbe from R. mucronata and A. ilicifolius against $E$. coli indicated that two microbial isolates from $R$. mucronata were active against 
MDR strain E. coli and five isolates from A. ilicifolius were active against MDR strain $E$. coli. Qualitative test results of Symbiont Microbe from $R$. mucronata and A. ilicifolius against $V$. harveyi indicated that two microbial isolates from $R$. mucronata were active against MDR strain $V$. harveyi and four isolates from A. ilicifolius were active against MDR strain $V$. harveyi (Table 1).

The qualitative test results of microbial isolates from $R$. mucronata indicated that 8 of 16 isolates showed potential as antimicrobial agents against MDR strain S. aureus, of which isolates codes are RM1, RM2, RM5, RM9, RM10, RM11, RM12, and RM15. The remaining 8, namely isolates RM3, RM4, RM6, RM7, RM8, RM13, RM14, and RM16 did not show any antimicrobial properties against MDR strain $S$. $a u$ reus. The qualitative test results of microbial isolates from the mangrove species A. ilicifolius indicated that eight isolates showed antimicrobial properties, while the remaining six did not show antimicrobial activity against MDR strain $S$. aureus. The isolates indicating antimicrobial properties were $\mathrm{AC} 1, \mathrm{AC} 2, \mathrm{AC} 4, \mathrm{AC} 5$, AC9, AC10, AC12, and AC14. The isolates that did not indicate antimicrobial properties were AC3, AC6, $\mathrm{AC} 7, \mathrm{AC} 8, \mathrm{AC} 11$, and $\mathrm{AC} 13$.

a)

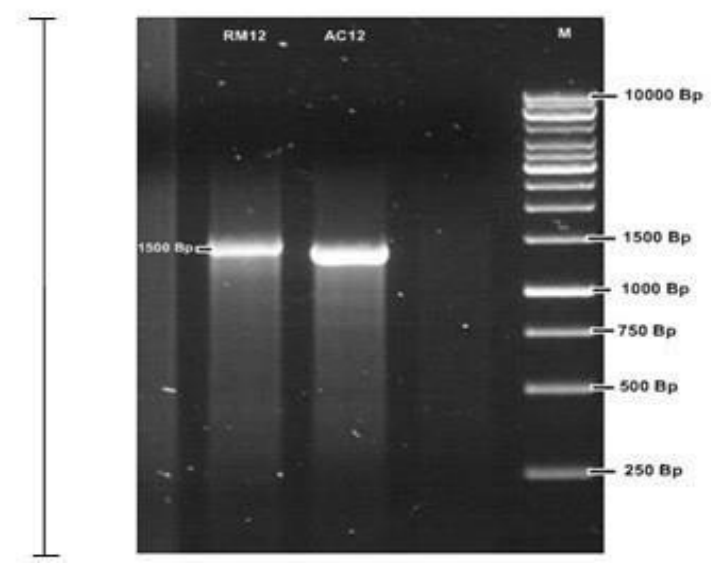

b)

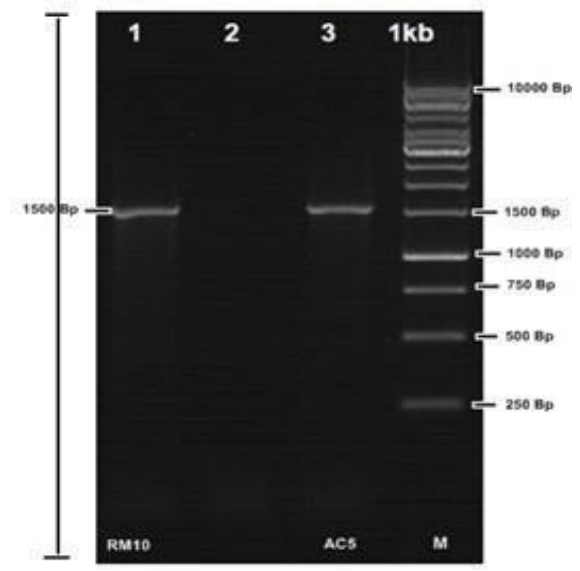

Out of 16 microbial isolates from $R$. mucronate showed antimicrobial properties against MDR strain $E$. coli, namely isolates RM10 and RM12. The testing of ilicifolius symbiont microbes against MDR strain $E$. coli showed five out of 14 isolates with antimicrobial properties: AC5, AC6, AC7, AC8, and AC9. Out of 16 microbial isolates from $R$. mucronata showed antimicrobial properties against MDR strain $V$. harveyi, namely isolates RM10 and RM14. And for microbial isolates from A. ilicifolius, four out of 14 microbial isolates, namely AC2, AC4, AC5 and AC12, showed antimicrobial properties against MDR strain $V$. harveyi (Table 1).

\subsection{Quantitative Antimicrobial Activity Test against MDR Strains}

The quantitative antimicrobial test was performed using agar diffusion method in accordance to Kirby-Bauer principles, using $8 \mathrm{~mm}$ paper disks. The quantitative test found eight isolates from $R$. тисronata, namely isolates RM1, RM2, RM3, RM5, RM7, RM10, RM11, and RM12, with antimicrobial properties against MDR strain $S$. aureus (Table 2). The test also found that 6 microbial isolates from A. ilicifolius with potential to be used as antimicrobial agents, namely isolates $\mathrm{AC} 1, \mathrm{AC} 2, \mathrm{AC} 5, \mathrm{AC} 10, \mathrm{AC} 12$, and $\mathrm{AC} 14$.

Figure 1. a)16S rDNA Amplification of RM12 and AC 12 (M : DNA Marker), b)16S rDNA Amplification of RM10 and AC 5. (M : DNA Marker)

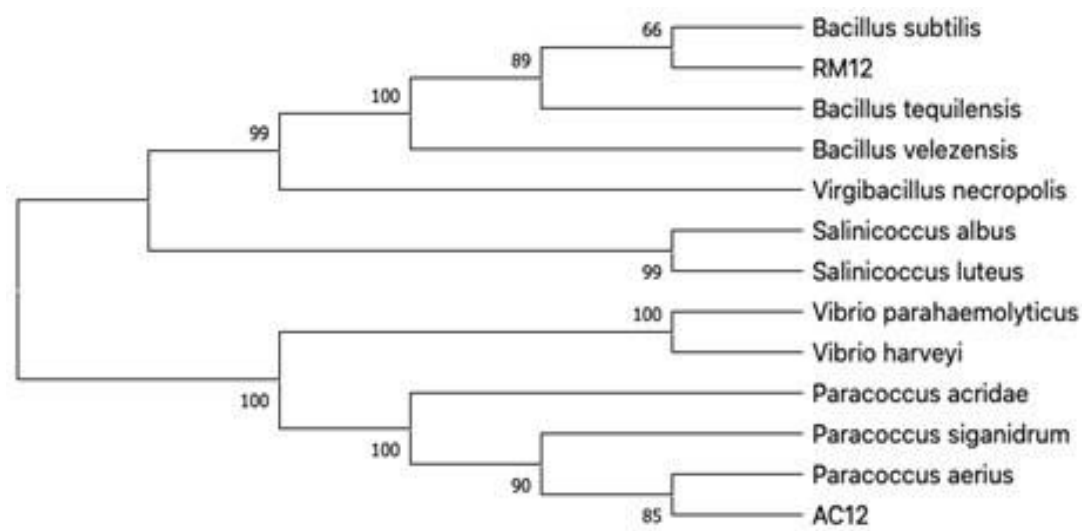

Figure 2. The phylogenetic tree describes the match between isolate RM12 and B. subtilis, and the match between isolate AC12 and Paracoccus aerius, using the interface of the program Tree View. 
JIPK. Volume 13 No 2. November 2021 / Exploration of Antimicrobial Potency of Mangrove Symbiont against....

Table 1. Antimicrobial activity qualitative test of mangrove symbiont microbe against S. aureus, E. coli and V. Harveyi

\begin{tabular}{|c|c|c|c|c|c|c|c|}
\hline \multirow{2}{*}{ Isolates } & \multicolumn{3}{|c|}{ Test microbes } & \multirow{2}{*}{ Isolates } & \multicolumn{3}{|c|}{ Test microbes } \\
\hline & S. aureus & E.coli & V.harveyi & & S. aureus & E.coli & V.harveyi \\
\hline RM.10.1.1 & + & - & - & AC. 10.1 .1 & + & - & - \\
\hline RM.10.1.2 & + & - & - & AC. 10.1 .2 & + & - & + \\
\hline RM.10.1.3 & - & - & - & AC. 10.1 .3 & - & - & - \\
\hline RM.10.1.4 & - & - & - & AC.10.1.4 & + & - & + \\
\hline RM.10.1.5 & + & - & - & AC. 10.1 .5 & + & + & + \\
\hline RM.10.2.6 & - & - & - & AC.10.1.6 & - & + & - \\
\hline RM.10.2.7 & - & - & - & AC. 10.1 .7 & - & + & - \\
\hline RM.10.3.1.8 & - & - & - & AC. 10.2 .8 & - & + & - \\
\hline RM.10.3.2.9 & + & - & - & AC. 10.3 .1 .9 & + & + & - \\
\hline RM.10.3.2.10 & + & + & + & AC. 10.3 .2 .10 & + & - & - \\
\hline RM.10.4.1.11 & + & - & - & AC. 10.4 .1 .11 & - & - & - \\
\hline RM.10.4.1.12 & + & + & - & AC. 10.4 .2 .12 & + & - & + \\
\hline RM.10.4.2.13 & - & - & - & AC. 10.5 .1 .13 & - & - & - \\
\hline RM.10.5.1.14 & - & - & + & AC. 10.5 .2 .14 & + & - & - \\
\hline RM.10.5.1.15 & + & - & - & & & & \\
\hline RM.10.5.2.16 & - & - & - & & & & \\
\hline
\end{tabular}

Table 2. Antimicrobial activity quantitative test of mangrove symbiont microbe against $S$. aureus

\begin{tabular}{|c|c|c|c|c|}
\hline Parameters & Isolates & $\begin{array}{l}\text { Zone of Inhibition } \\
\text { Diameter }(\mathrm{mm})\end{array}$ & Isolates & $\begin{array}{l}\text { Zone of Inhibition } \\
\text { Diameter (mm) }\end{array}$ \\
\hline \multirow{8}{*}{ S. aureus } & RM.10.1.1 & 9.08 & AC. 10.1 .1 & 9.6 \\
\hline & RM.10.1.2 & 10.30 & AC. 10.1 .2 & 9.28 \\
\hline & RM.10.1.3 & 8.52 & AC. 10.1 .5 & 10.16 \\
\hline & RM.10.1.5 & 11.21 & AC. 10.3 .2 .10 & 10.03 \\
\hline & RM.10.2.7 & 9.07 & AC. 10.4 .2 .12 & 12.32 \\
\hline & RM. 10.3 .2 .10 & 12.20 & AC. 10.5 .2 .14 & 10.20 \\
\hline & RM.10.4.1.11 & 10.22 & & \\
\hline & RM.10.4.1.12 & 12.38 & & \\
\hline \multirow{5}{*}{ E. Coli } & RM.10.3.2.10 & 11.22 & AC. 10.1 .5 & 10.76 \\
\hline & RM. 10.4.1.12 & 10.56 & AC. 10.1 .6 & 10.42 \\
\hline & & & AC. 10.1 .7 & 10.33 \\
\hline & & & AC. 10.1 .8 & 10.23 \\
\hline & & & AC.10.3.1.9 & 10.62 \\
\hline \multirow{4}{*}{ V. harveyi } & RM. 10.3 .2 .10 & 10.80 & AC. 10.1 .2 & 10.47 \\
\hline & RM.10.4.1.14 & 10.13 & AC. 10.1 .4 & 10.53 \\
\hline & & & AC. 10.1 .5 & 10.46 \\
\hline & & & AC. 10.4 .2 .12 & 10.58 \\
\hline
\end{tabular}

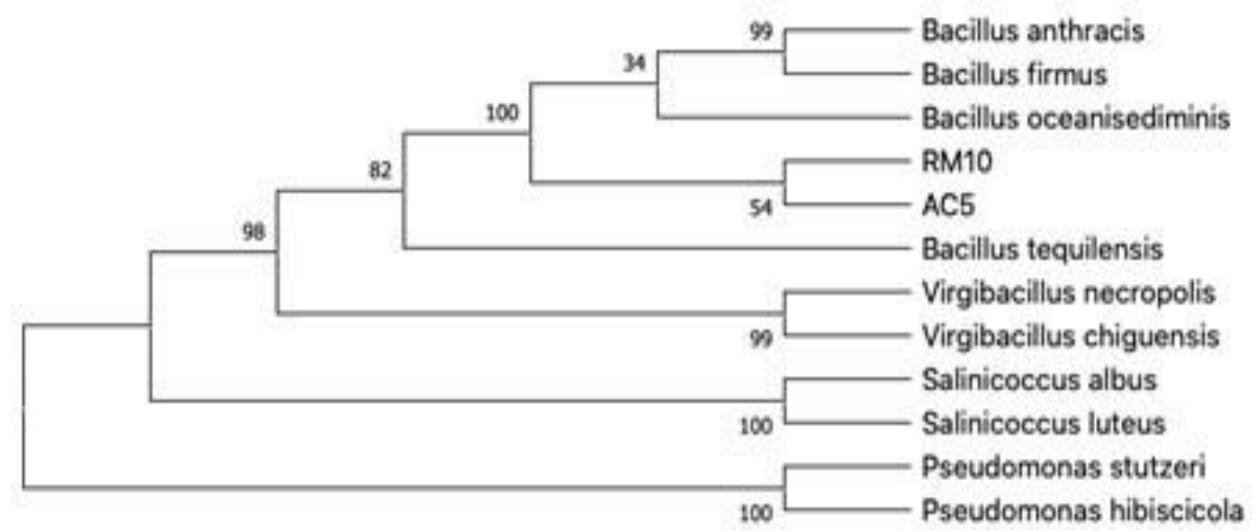

Figure 3. Phylogenetic tree showing the relative match of isolate RM10 and isolate AC5 using the program Tree View 
Table 3. BLAST homology of mangrove symbiont microbe

Isolates Relative Match

\begin{tabular}{|c|c|c|c|}
\hline RM12 & Bacillus subtilis & $97 \%$ & MN696502.1 \\
\hline $\mathrm{ACl} 12$ & Paracoccus aerius & $99 \%$ & NR_157753.1 \\
\hline RM10 & Bacillus oceanisediminis & $94 \%$ & MH283842.1 \\
\hline $\mathrm{AC} 5$ & Bacillus firmus & $76 \%$ & EU418717.1 \\
\hline
\end{tabular}

Based on the ability to inhibit the growth of pathogenic microbe by the diameter of inhibition zone, one isolate, RM 12 with $12.38 \mathrm{~mm}$ diameter of inhibition zone, from $R$. mucronata was selected, meanwhile from A. ilicifolius, isolate AC 12 was with $12.32 \mathrm{~mm}$ of inhibition zone diameter was chosen. The quantitative test found two isolates from $R$. mucronata, namely isolates RM10 and RM12, with antimicrobial properties against MDR strain E. coli, with the best isolate being RM10, which produced $11.22 \mathrm{~mm}$ of inhibition zone diameter. The test found five isolates from A. ilicifolius with promising antimicrobial properties, namely isolates AC5, AC6, AC7, AC8, and AC9. The best A. ilicifolius microbial isolate, AC5, produced $10.76 \mathrm{~mm}$ of inhibition zone diameter against MDR strain E. coli.

The test found that against MDR strain $V$. harveyi, two isolates from $R$. mucronata, namely isolates RM10 and RM14, with antimicrobial properties, with the best isolate being RM10, which produced $10.80 \mathrm{~mm}$ of inhibition zone diameter. The same test found four isolates from A. ilicifolius with promising antimicrobial properties, namely isolates $\mathrm{AC} 2, \mathrm{AC} 4, \mathrm{AC} 5, \mathrm{AC} 8$, and AC12. The best $A$. ilicifolius isolate, $\mathrm{AC} 12$, produced

$10.58 \mathrm{~mm}$ of inhibition zone diameter against MDR strain $V$. harveyi.

\subsection{DNA Amplification}

A total of two isolates, namely isolate RM12 and $\mathrm{AC} 12$, of which each has 1500 base pairs according to comparison using DNA marker was shown with single band (Figure 1a). Meanwhile, two isolates, namely isolate RM10 and AC5, of which each has approximately 1500 base pairs according to comparison using DNA marker was also shown with single band (Figure 1b).

\subsection{Molecular Phylogenetic Analysis}

Homology tracing of $16 \mathrm{~S}$ rDNA sequences of isolates RM12, AC12, RM10, and AC5 with DNA sequences of the GeneBank database using the BLAST system resulted in the homology of each bacterial isolate (Table 3). The match value between isolate RM12 with the sequence in the database was approximately $97 \%$, isolate AC12 was approximately 99\%, RM10 was approximately 94\%, and for isolate AC5 was approximately $76 \%$. The findings indicated that the molecu- lar identification of the symbiont microbes represented match up to the genus level. The phylogenetic tree describes the match between isolate RM12 and B. subtilis, and the match between isolate AC12 and P. aerius (Figure 2). The relative matching of isolates RM10 and AC5 using Tree View indicated that the isolates were most identical to $B$. oceanisediminis and B. firmus respectively. Isolate RM10 and isolate AC5 have the relative match in Phylogenetic tree (Figure 3)

Secondary metabolites are compounds that are synthesized by an organism not to meet its basic needs, but to preserve its existence in interaction with the ecosystem (Mitri and Foster, 2013). Secondary metabolism plays a role in the survival of a species in the struggle against other organisms (Lopanik, 2014). Secondary metabolites can be used as self-defence mechanism against predators as sex attractor and pheromones (Demain and Fang, 2000). Chemical compounds produced by microbial symbionts that can block these undesirable microbial organisms are categorized as antibiotics. The term antibiotic comes from anthibios, which means substances produced by a microorganism in small amounts that can inhibit the development of or kill other organisms (Kelsic et al., 2015)

The results of this study showed that the microbial symbionts of $R$. mucronata and A. ilicifolius 
JIPK. Volume 13 No 2. November 2021 / Exploration of Antimicrobial Potency of Mangrove Symbiont against....

have anti-microbial activity against MDR strain bacteria from S. aureus, V. harveyi, and E. coli. The findings indicated that microbial symbiont of mangrove produced secondary metabolites which acted as antimicro- bial agents. Antimicrobial agents are compounds which kill or inhibit the reproduction of microbes. Therefore, this medicine group is useful in treating bacterial infec- tion (Li et al., 2017). The performance of antimicrobi- al agents are affected by several factors, among which are the concentration of the compound, the number of microbial species, temperature, the existence of other organic compounds, and acidity levels (Gómez-García et al., 2019; Peh et al., 2020). The results of researchon mangroves show that mangroves contain very strong tannins (Pringgenies et al., 2017). Tannin compounds have known potential as antibacterial. Tannins are plant poly phenolic compounds which bind to proteins, aminoacids, alkaloids and precipitate them. They are known antimicrobial biomolecules (Kurhekar, 2016). Thus, the results of the study showing that symbiotic bacteria have the potential as antibacterial in MDR bacteria are suspected because they have compounds that are similar to their host. The results showed that there were four microbial isolates which had potential as MDR anti- microbial agents, namely RM12 isolate which showed homology (97\%) with B. subtilis, RM10 isolate which showed homology (94\%) with $B$. oceanisediminis, $\mathrm{AC} 12$ isolate which showed homology (99\%) with P. aerius, and AC5 isolate showing homology (76\%) with A. firmus. This finding indicated that among the sym- biont microbes of mangrove with antimicrobial MDR potential are the genus Bacillus and Paracoccus.

The microbe of the genus Bacillus is agrampositive rod-shaped bacterium and a member of the phylum Firmicutes, can be aerobic and obligate aer-obes (dependent on oxygen), or facultative anaerobes (have the ability to be aerobic or anaerobic). Microbes from this genus will be tested positive for catalase en- zymes when there is oxygen used or present (Kaushal etal., 2018). Bacillus can be found in a variety of environments and includes free-living species (non-parasitic) and parasitic pathogens (Celandroni et al.,2016). Under stressful environmental conditions, Bacillus can produce oval endospores, which are not true 'spores', with which they can reduce themselves and remain dormant for long periods of time. This characteristic at first defined the genus, but not all of these species are closely related, and many have been transferred to other genera from Firmicutes (Hashmi et al., 2020).

The genus Paracoccus is one of the most distantly related of the Proteobacteria to E. coli as judged by $16 \mathrm{~S}$ rRNA sequence. For many years, the sole representative of the genus was $P$. denitrificans. The original selection of this species was based on its ability to convert nitrate into molecular nitrogen. The genus Paracoccus has been known to produce antimicrobial compounds (Lee et al., 2012a). The microbe Paracoccus sp. MBIC4019 is also found in Pleuroploca trapesium from Ternate waters, and has been indicated to have antimicrobial properties (Pringgenies and Renta, 2014).

Symbiotic bacteria of the genus Bacillus are known to be found in several hosts that live in the sea, namely in mangroves (Pringgenies et al., 2015), sea cucumber (Pringgenies et al., 2019; Santosa et al., 2020), molluscs (Bahry and Pringgenies, 2016), sediment (Ariyanto, 2019), and fish (Pringgenies et al., 2021). This indicates that Bacillus has natural affinity in ma- rine environment, and that they may be categorized as pathogenic or non-pathogenic. Several non-pathogenic species that have potential as antimicrobial MDR agents are B. subtilis, B. firmus, and B. oceanissediminis. The microbial consortium of $B$. subtilis is known to break down waste into compost (Pringgenies et al., 2018), and research results show that compost produced has high concentrations of Nitrogen and Phosphorus (Pringgenies et al., 2016).

B. circulans are named so because the inside of the colony flows in a circular pattern. This micro- bial species is classified into Bacillaceae family and is grampositive, rod-shaped, and motile with peritrichous flagella. B. firmus also produces endospores (Alebouy eh et al., 2011). This species is commonly found in soil, wastewater, food, and baby bile. This microbe can be isolated from the intestines of bee larvae. B. circu-lans is a pathogen that is known to cause fatal sepsis in immuno-compromised patients (Alebouyeh et al., 2011). The finding is very interesting because the results of this study found that $B$. circulans in symbiosis 
with mangrove host has the potential as antimicrobial agent against MDR strain pathogens. Studies of DNA linkages and G C (The guanine-plus-cytosine) analysis showed that most of the strains analyzed were incorrectly classified as B. firmus (Susič et al., 2020). This results in the phenotypic heterogeneity of this species, which is not due to its inherent nature of genetically related strain variability, but because of the inclusion of genetically unrelated organisms. This means that $B$. circulans which was found and was shown to have MDR antimicrobial activity has a different strain.

The microbe $B$. oceanisediminis was found to have antimicrobial activity against MDR pathogens. This corroborates the findings of (Lee et al., 2012b) who stated that B. oceanisediminis 2691 is an aerobic, gram-positive, spore-forming, and quite halophilic bac- terium isolated from marine sediments of the Yellow Sea coast, South Korea. It is also known that the design of the genome sequence of $B$. oceanisediminis 2691 may have an important role in bioremediation of marinesediments.

\section{Conclusion}

The results of this study found that symbiont microbe of mangrove $R$. mucronata and A. ilicifolius have the potential as antimicrobial agents against MDR strain pathogens. Of all the isolates obtained from the mangrove samples, four isolates showed significant antimicrobial potential. R. mucronata and A. ilicifolius are shown to have the largest inhibition diameter zone against $S$. aureus with the diameter of $12.38 \mathrm{~mm}$ and $12.32 \mathrm{~mm}$ respectively. Molecular analyses of RM12 isolate showed $97 \%$ homology with Bacillus subtilis, of RM10 isolate showed 94\% homology with B. ocean-isediminis, of AC12 isolate showed $99 \%$ homology with P. aerius, and of AC5 isolate showed $76 \%$ homology with B. firmus.

\section{Acknowledgement}

We thank to the head of the Marine Science department Departement, Faculty of Fisheries and Marine Science, Universitas Diponegoro Semarang for allowed and facilitated us to do this project.

\section{Authors' Contributions}

All authors have contributed to the final manuscript. The contribution of each author as follows, Delianis pringgenies; contributed ideas, data generation, data analysis, funding, revised and perfected sentenc-es and vocabulary in the publication manuscript, and a project coordinator. Wilis Ari Setyati, Ali Djenaedi, and Rini Pramesti; devised the main conceptual ideas and critical revision of the article. Meanwhile Siti Rudiyan- ti, and Dafit Ariyanto; contributed manuscript prepara- tion and submittion. All authors discussed the results and contributed to the final manuscript.

\section{Conflict of Interest}

The authors declare that have no conflict of interests.

\section{Funding Information}

This project is implemented from members' independent funds into a research project.

\section{Reference}

Alebouyeh, M. P. G. O., Tajbakhsh, M., Tajeddin, E.

S. J. S., \& Nazemalhosseini, E. (2011). Fatal sepsis by Bacillus circulans in an immunocompromised patient. Iranian Journal of Microbiology, 3(3):156-158.

Altarugio, R., Vellano, I. H. B., Moraes, A. C. I., Milbradt, E. L., Filho, R. L. A., Guimarães-Okamo- to, P. T. C., Padovani, C. R., \& Okamoto, A. S. (2018). In vitro probiotic selection and characteri- zation of Lactobacillus spp. isolated from healthy domesticated Turkeys. Journal of Applied Poultry Research, 27(1):81-91.

Ariyanto, D. (2019). Food preference on Telescopi-um telescopium ( Mollusca: Gastropoda ) basedon food sources in mangrove. Plant Archives, 19(1):913-916.

Ariyanto, D., Bengen, D. G., Prartono, T., \& Wardiatno, Y. (2018a). Short Communication: The relationship between content of particular metabolites 
of fallen mangrove leaves and the rate at which the leaves decompose over time. Biodiversitas, 19(3):780-785.

Ariyanto, D., Bengen, D. G., Prartono, T., \& Wardiatno, Y. (2018b). The association of Cassidula nucleus (Gmelin 1791) and Cassidula angulifera (Petit 1841) with mangrove in banggi coast, Central Java, Indonesia. AACL Bioflux, 11(2):348-361.

Ariyanto, D., Bengen, D. G., Prartono, T., \& Wardiatno, Y. (2019a). The physicochemical factors and litter dynamics (Rhizophora mucronata Lam. and Rhizophora stylosa Griff) of replanted mangroves, Rembang, Central Java, Indonesia. Environment and Natural Resources Journal, 17(4):11-19.

Ariyanto, D., Gunawan, H., Puspitasari, D., Ningsih,

S. S., Jayanegara, A., \& Hamim, H. (2019b). the differences of the elements content in Rhizophora mucronata leaves from Asahan Regency, North Sumatra, Indonesia. Polish Journal of Natural Sciences, 34(4):481-491.

Ariyanto, D., Bengen, D. G., Prartono, T., \& Wardiatno, Y. (2020). Distribution and abundance of Cerithideopsilla djadjariensis (Martin 1899) (Pot- amididae) on Avicennia marina in Rembang, Cen- tral Java, Indonesia. Egyptian Journal of Aquatic Biology and Fisheries, 24(3):323-332

Badieyan, S., Dilmaghani-Marand, A., Hajipour, M. J., Ameri, A., Razzaghi, M. R., Rafii-Tabar, H., Mah- moudi, M., \& Sasanpour, P. (2018). Detection anddiscrimination of bacterial colonies with muel- ler matrix imaging. Scientific Reports, 8(1):1-10.

Bahry, M. S., \& Pringgenies, D. (2016). Isolasi bakteri simbion moluska penghasil senyawa antibakteri multi drug resistant (MDR). Prosiding Seminar nasional Tahunan \& Ke-V Hasil-Hasil Penelitian Perikanan Dan Kelautan, pp. 493-499.

Balouiri, M., Sadiki, M., \& Ibnsouda, S. K. (2016). Methods for in vitro evaluating antimicrobial activity: A review. Journal of Pharmaceutical Analysis, 6(2):71-79.
Celandroni, F., Salvetti, S., Gueye, S. A., Mazzantini, D., Lupetti, A., Senesi, S., \& Ghelardi, E. (2016). Identification and pathogenic potential of clin- ical Bacillus and Paenibacillus isolates. PLoS ONE, 11(3):1-13

Demain, A. L., \& Fang, A. (2000). The natural functions of secondary metabolites. Advances in Biochem-ical Engineering/Biotechnology, 69:1-39.

Gómez-García, M., Sol, C., De Nova, P. J. G., Puyalto, M., Mesas, L., Puente, H., Mencía-Ares, Ó., Miranda, R., Argüello, H., Rubio, P., \& Carvajal,

A. (2019). Antimicrobial activity of a selection of organic acids, their salts and essential oils against swine enteropathogenic bacteria. Porcine Health Management, 5(32):1-8

Hashmi, I., Bindschedler, S., \& Junier, P. (2020). Firmicutes. In N. Amaresan, M. Senthil Kumar, K. Annapurna, K. Kumar, A. Sankaranarayanan (Eds.), Beneficial Microbes in Agro-Ecology. Cambri d ge : Academic Press

Jiang, L., Wang, F., Han, F., Prinyawiwatkul, W., No,

H. K., \& Ge, B. (2013). Evaluation of diffusion and dilution methods to determine the antimicro- bial activity of water-soluble chitosan derivatives. Journal of Applied Microbiology, 114(4):956-963.

Kaushal, J., Mehandia, S., Singh, G., Raina, A., \& Arya, S. K. (2018). Catalase enzyme: Application in bioremediation and food industry. Biocataly- sis and Agricultural Biotechnology, 16:192-199.

Kelsic, E. D., Zhao, J., Vetsigian, K., \& Kishony, R. (2015). Counteraction of antibiotic production and degradation stabilizes microbial communities. Nature, 521:516-519

Kurhekar. J. V. (2016). Tannins - antimicrobial chemical components. International Journal of Technology and Science, 9(3): 5-9

Lee, L. H., Cheah, Y. K., Nurul Syakima, A. M., Shiran, M. S., Tang, Y. L., Lin, H. P., \& Hong, K. (2012a). Analysis of Antarctic protobacteria by PCR finge $r$ printing and screening for antimicrobial secondary metabolites. Genetics and Molecular Research, 11(2):1627-1641. 
Lee, Y. J., Lee, S. J., Jeong, H., Kim, H. J., Ryu, N., Kim, B. C., Lee, H. S., Lee, D. W., \& Lee, S. J. (2012b). Draft genome sequence of Bacillus oceanisediminis 2691. Journal of Bacteriology, 194(22):6351-6352.

Li, J., Xie, S., Ahmed, S., Wang, F., Gu, Y., Zhang, C., Chai, X., Wu, Y., Cai, J., \& Cheng, G. (2017). Antimicrobial activity and resistance: Influencing factors. Frontiers in Pharmacology, 8:1-11.

Lopanik, N. B. (2014). Chemical defensive symbioses in the marine environment. Functional Ecology, 28(2):328-340

Mitri, S., \& Foster, K, R. (2013). The genotypic view ofsocial interactions in microbial communities. An- nual Review of Genetics, 47:247-273.

Ningsih, S.S., Ariyanto, D., Puspitasari, D., Jayanegara, A., Hamim, H., \& Gunawan, H. (2020). The amino acid contents in mangrove Rhizophora mucronata leaves in Asahan, North Sumatra, Indonesia. E3S Web of Conferences, 151(01047):1-3.

Osti, R., Tanaka, S., \& Tokioka, T. (2009). The importance of mangrove forest in tsunami disaster mitigation. Disasters, 33(2):203-213.

Peh, E., Kittler, S., Reich, F., \& Kehrenberg, C. (2020). Antimicrobial activity of organic acids against Campylobacter spp. and development of combina- tions - a synergistic effect? PLOS ONE, 15(9):1-13.

Pringgenies, D., Setyati, W. A., Wibowo, D. S., \& Djunaedi, A. (2020). Aktivitas antibakteri ekstrak jeruju acanthus ilicifolius terhadap bakteri Multi Drug Resistant. Jurnal Kelautan Tropis, 23(2):145-156.

Pringgenies. D., Pratiwi, A. H. D., Yudiati, E., Azizah, R., \& Susilo, E. S. (2017). Biopigment trac- ing of mangrove Rhizophora mucrota leaf and bark waste and its application for batik dyeingby multiple fixations. Proceeding of Basic sci-ences for improving survival and quality of life. Malang: Universitas Brawijaya.
Pringgenies, D., Azmi, I., Ridho, A., \& Idris, R. (2016). Exploration of bacteria symbionts mangrove waste for the production of decomposter. Oceanography, 4(1):33

Pringgenies, D., Jumiati, M., \& Ridho, A. (2015). Antibacterial activity test of nudibranches polka

- dot (Jorunna funebris) (Gastropods: Molusc) extract against multi drug resistant (MDR). Ilmu Kelautan: Indonesian Journal of Marine Sci- ences, 20(4):195-206.

Pringgenies, D., \& Renta, P. P. (2014). Bacterial symbiont Gastropoda Pleuroploca trapezium from Ternate, as alternative antibacterial MDR. ILMU KELAUTAN: Indonesian Journal of Marine Sciences, 19(1):55-62.

Pringgenies, D., Rudiyanti, S., \& Yudiati, E. (2018). Exploration of sea cucumbers Stichopus hermanii from Karimunjawa Islands as production of marine biological resources. IOP Conference Se-ries: Earth and Environmental Science, 116:1-8.

Pringgenies, D., Yudiati, E., Djunaedi, A., Santosa, G. W., \& Koesoemadji. (2019). Explorations of symbiotic microbe from sea cucumber gut as an antimulti-drug resistant microbe agent for utilization in hand sanitizer products. AACL Bioflux, 12(3):737747.

Quadros, A. F., \& Zimmer, M. (2017). Dataset of true mangroves plant species traits. Biodiversity Data Journal, 5(e22089):1-20.

Ragavan, P., Saxena, A., Mohan, P. M., Jayaraj, R. S. C., \& Ravichandran, K. (2015). Taxonomy and distribution of species of the genus Acanthus (Acanthaceae) in mangroves of the Andaman and Nicobar Islands, India. Biodiversitas, 16(2):225-236.

Santosa, G. W., Djunaedi, A., Susanto, A. B., Pringgenies, D., \& Ariyanto, D. (2020). Characteristics of bioactive compounds of Holothuria atra (Jae- ger, 1833) associated bacteria. AACL Bioflux, 13(4): 2161-2169.

Sune, D., Rydberg, H., Augustinsson, Å. N., Serrander, L., \& Jungeström, M. B. (2020). Optimization of 
JIPK. Volume 13 No 2. November 2021 / Exploration of Antimicrobial Potency of Mangrove Symbiont against....

16S rRNA gene analysis for use in the diagnos tic clinical microbiology service. Journal of Microbiological Methods, 170:105854

Susič, N., Janežič, S., Rupnik, M., \& Stare, B. G. (2020). Whole genome sequencing and comparative genomics of two nematicidal Bacillus strains reveals a wide range of possible virulence factors. G3: Genes, Genomes, Genetics, 10(3):881-890.

Ventola, L. (2015). The antibiotic resistance crisis.
Pharmacy and Therapeutics, 40(4):277-283.

Yang, Y., Yang, S., Li, J., Deng, Y., Zhang, Z., Xu, S., Guo, W., Zhong, C., Zhou, R., \& Shi, S. (2015). Transcriptome analysis of the holly mangrove Acanthus ilicifolius and its terrestrial relative, Acanthus leucostachyus, provides insights into adaptation to intertidal zones. BMC Genomics, 16(605):1-12 